\section{Relational Dependence}

in a Culture of Self-Creation:

A Theological Query into the

Health of the Medical World
The Linacre Quarterly 2020, Vol. 87(4) 438-443

(C) Catholic Medical Association 2020 Article reuse guidelines: sagepub.com/journals-permissions DOI: 10.1 1 177/0024363920949785 journals.sagepub.com/home/lqr

\author{
John Nepil, STD' ${ }^{\prime}$
}

\begin{abstract}
Half of the medical professionals in the United States are experiencing symptoms of burnout. From the perspective of theological anthropology, this dehumanizing aspect of the field is not reducible to ethical failures, for it is rooted in the radically new worldview known as self-creation. As an implicit denial of Christian understanding of creation, self-creation entails a rejection of relationality and dependence-both proper to the Revelation of Jesus Christ. This article proposes that this lost Christian patrimony is intimately connected to the increasingly unhealthy dependence we place upon modern medicine. Relying on theologian Joseph Ratzinger, we will come to see that a recovery of relational dependence is not only necessary for the salvation of manbut the very health of the medical world at large.
\end{abstract}

\title{
Keywords
}

Dependence, Ratzinger, Relational ontology, Relationality, Theological anthropology

Recent studies have shown that over half of the physicians in the United States experience symptoms of burnout (Reith 2018,2). The numbers are similar for nurses, physician assistants, and - not surprisingeven higher for residents and medical students. That number is itself concerning but not as much as the rate of increase: 25 percent from four years prior. And to make things worse: this was life before the pandemic of 2020, the effects of which on the medical field we are only beginning to realize. What all this means is that the majority of people providing medical care to our country are experiencing physical exhaustion and emotional depletion to the point of burnout.

Writing as a theologian and not a medical professional, I am limited to observations in this regard. A proper diagnosis and the practicalities of reform can only come from within the medical field itself by those competent. But from this outsider's perspective, it seems as if the better we become at healing the patient's body, the more damage we do to the provider's soul.
In so much as burnout is a symptom of dehumanization, it is an anthropological problem, and every anthropological problem engages the Christian proposal-that the God-man Jesus Christ reveals man fully to himself. It is all too clear how systematically this Christian claim has been dismissed by the modern world, especially in the medical arena. But perhaps things have reached a point of desperation whereby one can revisit the Christian understanding of man.

Self-creation, opposed to the Christian vision of creation, has supplanted what was classically held: the view from which modern medicine was itself first derived. The assimilating culture of

\footnotetext{
' St. John Vianney Theological Seminary, Denver, CO, USA

Corresponding Author:

John Nepil, STD, St. John Vianney Theological Seminary, I 300 S. Steele St., Denver, CO 802 I0, USA.

Email: father.nepil@gmail.com
} 
self-creation not only rejects its Christian predecessor, it loses its very patrimony. In particular, with the loss of Christian humanism, we forfeit two indispensable keys to unlocking its mystery: relationality and dependence.

As the theologian Joseph Ratzinger observed, until modern man recovers relational dependence, he will remain existentially fragmented by the illusion of self-creation. This recovery is several: first, it is one of relationality, which reveals man's fundamental pattern; second, it is a question of dependence - or the basic truth of man - built upon these relational grounds. Last, if $\sin$ is the rejection of relational dependence, then the salvation of man involves not only its recovery, but the rejection of the spirit of self-creation. So too for the world of medicine: only by returning to the truth of relational dependence can it be restored to health.

\section{Relationality: The Fundamental Anthropological Pattern}

The first thing we are told about human persons is that they are made in the image and likeness of God (Genesis 1:27). This notion of imago Dei implies two things: a distinction and a relationship. The first is metaphysical, distinguishing the being of God as utterly distinct from the being of creation. One is divine, limitless, and necessary in himself; the other created, limited, and entirely contingent. Although this distinction may appear self-evident, it is in fact unique to the great mystery of God's revelation in Christ.

The clarity of this distinction creates the possibility of relationship. This too is metaphysical, as all created beings are sustained in existence by the self-sustaining God. But the relationship of God and man transcends this metaphysical rapport in a wholly unique way. When God endowed humanity with rational souls, he not only formed them as images of his divine life, he made them capable of sharing in it.

We begin then with a profound truth: man's selfunderstanding is not found within himself. Contrary to the modern mentality, he cannot define, interpret, or even understand who or even what he is by looking to himself. In God alone is his self-discovery, for he must find himself in relation to the mysterious origin of his being. In the end, he is imago Dei, a representational being intelligible only in light of the reality to which it points.

As man surrenders his desire for autonomous self-understanding, he opens anew to the mystery of God in Jesus Christ. In him, he encounters the central mystery of the Christian faith: the revelation of one God in three persons, unity in relationality. Man, being in relationship to God, is in fact in relationship with relationship itself. As Ratzinger explains, this carries new import into the meaning of imago Dei.

To be the image of God implies relationality. It is the dynamic that sets the human being in motion toward the totally Other. Hence it means the capacity for relationship; it is the capacity for God. Human beings are, as a consequence, most profoundly human when they step out of themselves and become capable of addressing God on familiar terms ... they are most profoundly themselves when they discover their relation to their Creator. (Ratzinger 1995, 48)

Man's spiritual capacities render him capable of relationship with God, a wholly different way of relating in creation. This is the hallmark of humanity - that human beings are distinctively relational, reflecting the essence of God. Being imago Dei is then not a static disposition but both relational and dynamic. The more that human persons acknowledge and live according to this innate relational nature, the more fully they become themselves.

In Christ we delve still more deeply, for in him is revealed how three divine persons express one essence in three relations. With creative touch, Ratzinger describes the three Trinitarian persons with prepositions. "The real God" he writes, "is by his very nature being-for (Father), being-from (Son), and being-with (Holy Spirit)" (Ratzinger 1996, 28). As one divine substance, the persons of the Trinity are not only in relation; they are their relations. The Father, origin of the divine life is being for; the Son, eternally generated by the Father, is being from; and the Holy Spirit, the spiration of their love, is being with. God is, as Ratzinger says, pure relativity, the perfection of relationship in the communion of love.

If man as imago Dei expresses divine relationality, then he must signify something of these three modes. In other words, the relations for, from, and with must be proper to the essence of man. And this Ratzinger calls his fundamental anthropological pattern.

Man, for his part, is God's image precisely in so far as the "from," "with" and "for" constitute the fundamental anthropological pattern. Whenever there is an attempt to free ourselves from this pattern, we are not on our way to divinity, but to 
dehumanization, which is the destruction of being itself through the destruction of the truth. (Ratzinger 1996, 28)

Man's essence is predetermined by the Trinitarian relations which he represents. He is born into existence with this pattern, which cannot be recreated. Trinitarian relationality, expressed as being for, from, and with, is woven into the fabric of man's being. It is the fundamental pattern of his life and the bedrock upon which he can understand the basic truth of his existence - that he lives in total dependence upon another.

\section{Dependence: The Primary Truth of the Person}

Creation, taken in its totality, exists in a state of dependence. Simply put: if it didn't cause itself, something else must have caused it. This causal dependence implies a limitation, the confines that delineate finitude. In metaphysical terms, this is called an essence, the co-principle of existence. To be a creature is to be dependent, and to be dependent is to be limited.

What was easily accepted by the ancients is now obstinately denied by modern man. Nowadays, man dismisses this dependence in order to define his selfunderstanding upon himself. But he cannot truly deny this most basic metaphysical fact: he is dependent, a creature of limitations. Joseph Ratzinger clarifies:

Human beings are dependent. They cannot live except from others and by trust. But there is nothing degrading about dependence when it takes the form of love, for then it is no longer dependence, the diminishing of self through competition with others. Dependence in the form of love precisely constitutes the self as self and sets it free, because love essentially takes the form of saying, "I want you to be." It is creativity, the only creative power, which can bring forth the other as other without envy or loss of self. Humans are dependent - that is the primary truth about them. And because it is, only love can redeem them, for only love transforms dependence into freedom ... we exist on the foundation of love. (Ratzinger 1995, 99)

For Ratzinger, the notion of dependence is not an artificial construct or social superstructure - it is the primary truth of the human being. This is, once again, rooted in the intrinsically relational structure of human existence; in that way, dependence is no more than the structure of human relationality. Human flourishing is discovered not by throwing off dependence but by configuring oneself to it.

In confronting human freedom, the notion of dependence moves from being a metaphysical fact to an existential challenge. Despite its finitude, my human will gives me an enduring sense of independence, autonomy, and self-definition. As moderns, we find this far more attractive than accepting a relational dependence we never chose, and so begins the path of self-assertion over and against the infinite freedom of God.

Like relationality, the starting point of the Christian understanding of freedom is not in man but in God. In uncreated perfection, God exercises the fullness of freedom. Man's freedom is a participation in God's, meaning that his dependence reaches all the way into the ethical sphere. As the theologian Charles Journet notes, only within the relationship of God can the truly dependent nature of human freedom be understood.

Freedom is not independence in relation to God ... freedom is to be found within God himself, as in its infinite source; the nearer I draw to God and the more I share in his rule over lower beings, the more I am free. My freedom is a dependence in relation to God, a dependence that gives me a power over and freedom of choice in regard to the lower things. (Journet 1996, 34)

If one attempts to ignore the question of God, one will never understand the dependent nature of human freedom. Infinite freedom within the mystery of the Trinity is a mystery of relationality. The realm of freedom can never transcend the realm of relationality, not even in God. If then all freedom is relational and creation is dependent, created freedom must be relationally dependent. We are dependent upon God not just in our being but in our every action.

\section{Sin, Salvation, and Self-Creation}

At the origins of human life, an historical act created the state known as original sin. It was an act that refused to accept the status of a dependent creature. It revealed the true nature of sin; its most basic distillation, Ratzinger notes, is "the rejection of relationality (Ratzinger 1995, 73)." Refusing the 
relational structure of freedom, man denies the basic truth of his existence, and rather than liberating himself, enters into a new slavery:

At the very heart of sin lies human beings' denial of their creatureliness, inasmuch as they refuse to accept the standard and the limitations that are implicit in it. They do not want to be creatures, do not want to be subject to a standard, and do not want to be dependent. They consider their dependence on God's creative love to be an imposition from without.... Human beings who consider dependence on the highest love as slavery and who try to deny the truth about themselves, which is their creatureliness, do not free themselves; they destroy truth and love. (Ratzinger 1995, 70-71)

In rejecting relational dependence, man has set down the path of his own destruction. He is wounded, incapable of freeing himself from his self-imposed slavery. He believed the primordial lie that he could transcend his limitations and become God. He is now alienated from his own nature and incomprehensible in and to himself. It is into this nature that God himself descends in the Incarnation. The salvation of man came about through the pure gift to creation of the Son by the Father. He who knew no limits took on our own in order to restore us to the basic truth of our being. In the God-man, creation saw again the beauty and integrity of relationality and its own possible restoration.

Although Christ has conquered sin, there always remains temptation. And as the priest-physicist Lorenzo Albacete notes, the law of temptation always follows the same logic of nondependence.

There is only one temptation. All particular temptations are expressions of this one original or "primordial" temptation. This is the temptation to believe that the fulfillment of the desires of the human heart depends entirely on us. Dependence on another leaves us at the mercy of what we cannot control. Therefore, we are tempted to reject all forms of dependence. The most radical form of dependence is love. Therefore, the original temptation is to deny that our existence is a pure and perfect gift of an infinite Love that deserves to be loved in return. The fullest revelation that God is love is the Incarnation of Christ. Therefore, the primordial temptation is to reject the
Incarnation and its consequences. (Albacete 2019, 130-31)

In the end, temptation and sin are always an assault on relationship, undermining trust in the other with accusation and deception. For as Ratzinger notes of original sin, "the first thing is not the denial of God but rather doubt about his covenant, about the community of faith" (Ratznger 1995, 66). To be healed from sin is about learning truth through belief, knowledge through relation. We must rebuild our lives not on our own isolation but on Jesus, the totally relational man. In his humanity, creation is restored to perfect relational dependence. He embraces the limitations of his existence not as confines to his autonomy but as privileges for a deeper reliance on the Father. With Ratzinger we can conclude: "The Son, who is by nature relationship and relatedness, reestablishes relationships ... It is precisely this dependence that is freedom, because it is truth and love." (Ratzinger, 1995)

In modernity, this logic of nondependence has been enshrined in the quest for self-made autonomy. In this is a twofold denial: that of Trinitarian relationality as the fundamental anthropological pattern and that of dependence as the basic truth of human existence. From the Christian perspective, this is the source of the spiritual crisis of the modern age. Once Trinitarian Revelation is disregarded, relationality becomes again accidental and, soon thereafter, metaphysically untethered. This leaves modern man as a stranger to himself, necessarily in relationships he find meaningless. It also creates a new worldview, one which has now supplanted the Christian one. In the void of dependence emerges the new ethos of self-creation.

Creation is defined as dependence, origin $a b$ alio [from another]. Its place is taken by the category of self-creation, which is accomplished through work. Since creation equals dependence, and dependence is the antithesis of freedom, the doctrine of creation is opposed to the fundamental direction of Marxist thought. (Ratzinger 1995, 91)

This notion of self-creation is entirely antithetical to the Christian vision of relation and dependence; it is, as Ratzinger describes, an affiliate of Marxism. If creation is now a project of the self, it can only be accomplished by action. What stands in the way of this task is the bond of alienation known as dependence. Any semblance of dependence is experienced 
as vexing and must be thrown off. This inevitably leads to a stark but necessary conclusion. Although he may now feel liberated from relational dependence, he has entered into the depths of "a hideous narcissism" (Ratzinger 1995, 34).

The salvation of man lies in embracing his relationality as dependence, which, paradoxically, is the only way for his finite freedom to be exercised in a truly free manner. It is the complete acceptance of his creatureliness - the fact of his existence. He is not himself when he is isolated and alone but only himself when he is with and in the other. Man is part of the great relational symphony of created being, and only in the acceptance of this can he truly be himself. "Every individual part derives its meaning from the whole, and the whole derives its meaning from its end-from Christ" (Ratzinger 1995, 9). Salvation stands and falls on the question of relation.

\section{The Future Health of the Medical World}

It is hard to imagine a time when we were more dependent on medical professions than in our present moment. Our days are filled with the latest virology reports, infection statistics, and public health protocols. Above all, we wait with hopeful expectation for the day that science will provide us with a vaccine for COVID-19-which promises us the return to normalcy.

But this dependence on the medical world is inimical. We now require herculean feats of healthcare providers, demands which crush the weak and deify the strong. The problem lies not with medical professionals but with us, whose excessive reliance on medicine is becoming increasingly dehumanizing. The pursuit of an intrinsic good-bodily health - is now the source of a new spiritual malaise. If we continue to press the medical industry, the end result could be catastrophic.

From a Christian perspective, the problem is simple: we have shifted our dependence from God to science. More specifically, when we lost our relationship to God, we lost our innate sense of dependence. But we are made for dependence, and it is the basic truth of our existence. So, we refounded it in modern medicine, placing all of our hopes in its promises. This newfound dependence begins in the belief that science is without limitation, capable of infinite progress and possibility. But as soon as we invest anything with limitlessness, we have made it God. And this seems to be more about us than anything else; in denying the limits of science, we reject our own creaturehood. In the end, science may be the projection of our self-divinization and medicine the locus of our self-creation.

What is needed today is a rightly ordered relational dependence. We begin again in God, who as infinitely perfect in himself is alone the being that is independent. From this, we recover creation-all that is apart from God. By the nature of contingent existence, created being is limited and thus essentially dependent. Man, who stands at the heart of creation, awakens to the fact of his creatureliness only when he understands himself in relationship to God. Seeing creation as dependent upon God and himself as created, he awakens to the basic truth of his existence: he is dependent. And he loves his dependence, precisely because it elicits the reverence and gratitude for which his heart was made.

Living relational dependence means conforming one's life to the fundamental pattern and basic truth of human existence; in that way, it is nothing more than living as we actually are. In a culture of selfcreation, much is at stake with our decision for or against relational dependence- - and not just for ourselves but the future health of the medical world.

\section{Declaration of Conflicting Interests}

The author(s) declared no potential conflicts of interest with respect to the research, authorship, and/or publication of this article.

\section{Funding}

The author(s) received no financial support for the research, authorship, and/or publication of this article.

\section{ORCID iD}

John Nepil, STD (D https://orcid.org/0000-00031890-6073

\section{References}

Albacete, Lorenzo. 2019. “Adoration Vigil for Holy Thursday." Magnificat (US Edition) 21, no. 1: 130-38. Journet, Charles. 1996. The Meaning of Grace. New York: Scepter.

Ratzinger, Joseph. 1995. In the Beginning. ... A Catholic Understanding of the Story of Creation and the Fall. Grand Rapids, MI: William B. Eerdmans.

Ratzinger, Joseph. 1996. "Truth and Freedom." Communio. International Catholic Review 23, no. 1: 16-35.

Reith, Thomas. 2018. "Burnout in United States Healthcare Professionals: A Narrative Review." Cureus 10, no. 12: $1-9$. 


\section{Biographical Note}

John Nepil, STD, is a priest in Denver, Colorado, and a member of the priestly association of the Companions of
Christ. Having finished a doctorate in dogmatic theology at the Pontifical University of Santa Croce in Rome, he is now a member of the academic and formation faculty of St. John Vianney Theological Seminary in Denver. 